\title{
Prediction of Some Water Quality Indices in River Yobe- Nigeria, through Annual Projections
}

\author{
Waziri Maimuna ${ }^{1, *}$, Ogugbuaja O. Victor ${ }^{2}$ \\ ${ }^{1}$ Department of Chemistry, Yobe State University, Damaturu. Nigeria \\ ${ }^{2}$ Department of Chemistry, University of Maiduguri. Nigeria
}

\begin{abstract}
Water quality assessment or monitoring involves the determination of a number of parameters using several analytical techniques which are usually cumbersome. In this study, an attempt was made to establish relationships between some water quality indicators which can be used to predict other related parameters in order to ease up the long experimental procedures involved. This was achieved by collecting water samples from six locations along river Yobe-Nigeria during the wet and dry seasons as well as the harmattan period. The conductivity, turbidity and total dissolved solids (TDS) of the samples were measured using standard analytical techniques. Results of the study showed both location and seasonal variations in levels of the conductivity and TDS but were within the World Health Organization (WHO) and Nigerian Industrial Standard (NIS) permissible limits for drinking water. However, the levels of turbidity which ranged from $11.33 \pm 2.16$ NTU to $21.83 \pm 3.97$ NTU exceeded the standard limits. Significant differences $(\mathrm{p}<0.05)$ in conductivity, TDS and turbidity were recorded between seasons at most of the locations. Based on the data obtained, annual variations were calculated and empirical relationships between these three variables were established. The relationships suggest that the quality of the river investigated can be monitored effectively by controlling the conductivity of the water. The relationships may also be applicable to surface waters which contain similar composition of ions in the water and can be used to predict levels of other related physicochemical parameters used in assessing quality of the surface water.
\end{abstract}

Keywords Relationships, Physicochemical Parameters, Prediction, Seasonal Variation, Harmattan Period

\section{Introduction}

Water pollution is a global problem and the complexity involved in assessment and monitoring of water quality may be associated with the vast potential sources of water pollution. It is also a fact that water analysis involves a multitude of parameters with a corresponding larger multitude of analytical techniques. Relationships between dependent and independent variables have been used to relate pollution indicators and estimate the quantity and quality of pollutants or indicators in water bodies[1-4]. Conductivity has been used as a standard water quality parameter $[5,6]$. It provides a clear view of the total ionic strength and extent of salinity as well as assesses the TDS in a water body. Studies have shown the importance of conductivity in geophysical mapping of polluted

Ground water and in separating hydrographs like wise in the establishment of empherical relationships with other water quality parameters[7-9]. Furthermore, the use of Geographical Information Systems to relate conductivity to

* Corresponding author:

maimunakadai@yahoo.com (Waziri Maimuna)

Published online at http://journal.sapub.org/fs

Copyright (C) 2012 Scientific \& Academic Publishing. All Rights Reserved other water quality parameters have been reported[10,11]. Water turbidity has also been related to bacterial population in drinking water[12].

The aim of this study is to establish relationships between annual variations in conductivity and other pollution indicators in order to establish an instant measurement methodology to predict other physicochemical water quality indicators in the area of study. The establishment of such relationships will provide an instant highlight on which parameter to concentrate on, in order to maintain the quality of the water.

\section{Materials and Methods}

\subsection{Determination of Conductivity and TDS}

Conductivity/TDS meter Hach model 44600 was used to measure the conductivity and TDS levels of all the samples. The procedures used were as contained in the manufacturer's manual for the equipment.

\subsection{Determination of Turbidity}

The turbidity of the water samples was determined using the absorbtimetric method of the Smart spectrophotometer (Lamotte model) with standard formazin solution as a 
reference. The procedures used were as contained in the manufacturer's manual for the equipment.

\subsection{Data Analysis}

Results obtained were expressed as mean \pm SD and statistically analysed for significance in variations between sampling locations. The t-test was used for variations betwe en seasons while variations between sampling locations by analysis of variance (ANOVA) Microsoft Excel+Analyse-it v. 2.10).Variations were considered significant at $\mathrm{p}<0.05$.

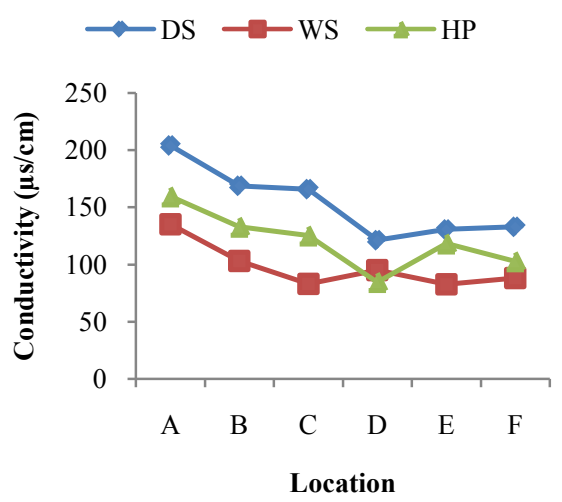

Figure 1. Seasonal variations of Conductivity $(\mu \mathrm{s} / \mathrm{cm})$ at different

Locations of River Yobe

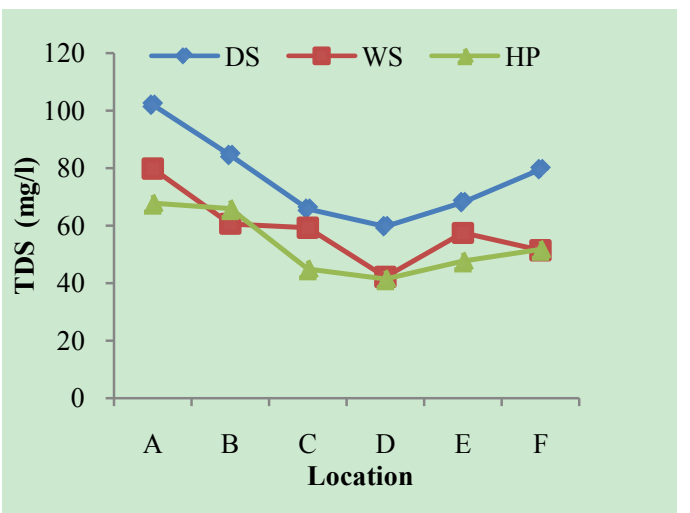

Figure 2. Seasonal variations of Total dissolved solids(mg/l) at different Locations of River Yobe

\section{Results and Discussion}

Conductivity ranged from $82.83 \pm 10.55 \mu \mathrm{s} / \mathrm{cm}$ (location E) to $204.00+45.37 \mu \mathrm{s} / \mathrm{cm}$ (location A). The highest value was recorded during the dry season and lowest during the harmattan period (Figure 1). Higher values of the conductiv ity may be due to increased ionic compounds for the water samples resulting in decrease in conductivity with increase in turbidity. The highest conductivity values recorded during the dry season may be attributed to high evapotranspiration and pollution from the use of manure and fertilizers for irrigation activities. Similar high conductivities values associated with evaporation from intensive agricultural activities in the Great Salt Lake in Utah and Mono Lake in
California have been reported[13, 14]. Low conductivity in the wet season lower than the harmattan values may be due to likely dilution from the enormous amount of rainfall and cleansing of the flooded waters. Significant differences $(p<0.05)$ were recorded within and between locations at most of the locations.

The seasonal variations of total dissolved solids (TDS) at all the locations are shown in Figure 2.

This followed similar pattern as that of conductivity since the amount of dissolved solids

in water affects its ability to conduct electricity, however, this was not the case in the harmattan period. The high levels of TDS during the harmattan period may be associated with compositions of complex particulate matter which is characteristic of the harmattan period[15]. This complex particulate matter consists of both inorganic and organic chemicals, as well as microbial entities[16, 17]. Similar Studies have shown that high rates of deposition of organic pollutants is responsible for high values of TDS and low DO in surface water[1] hence, the high TDS values in the harmattan period when compared to the dry season recorded in this study.

High concentrations of TDS can lower the water quality and cause water balance problems for individual organisms and aquatic life. Although there is no serious health effect associated with TDS ingestion in drinking water but earlier research revealed an inverse relationship between TDS concentrations in drinking water and the incidence of cancer, coronary heart disease and cardiovascular diseases[18-20].

Turbidity levels ranged from 11.33+2.16 NTU (location A) to $21.83+3.97 \mathrm{NTU}$ (location D) as shown in Figure 3. All the locations exceeded the 5NTU recommended turbidity level stipulated by WHO[21] and NIS[22]. Though rainfall and river flow are related to turbidity but high turbidity peaks were also noted during the harmattan period (Figure 3).

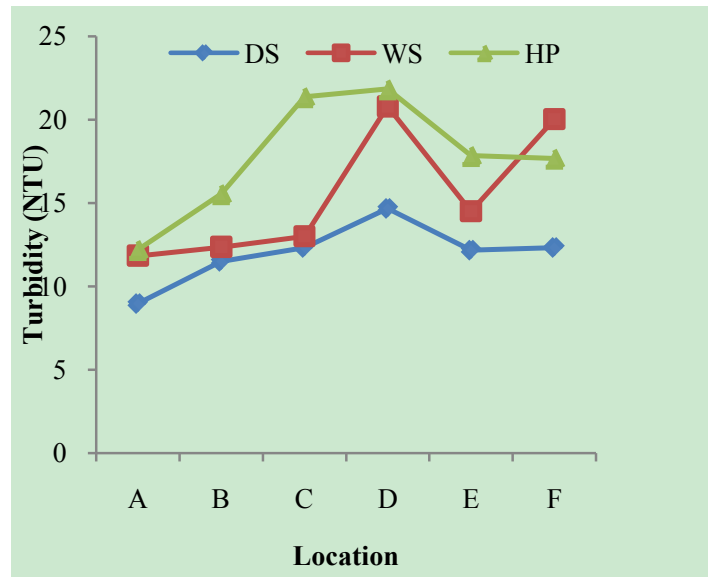

Figure 3. Seasonal variations of Turbidity (NTU) at different Locations of River Yobe

This may be due to decreased vegetation, decreased evapotranspiration and high particulate matter deposition during the dusty harmattan months. Inverse relationships were noted between turbidity and conductivity during the wet and dry seasons which agrees with the variations 
observed in Orange and Caledon Rivers during the dry seasons[23]. High conductivity values recorded after the rains in South African rivers was associated to presence of suspended pollutants[24].

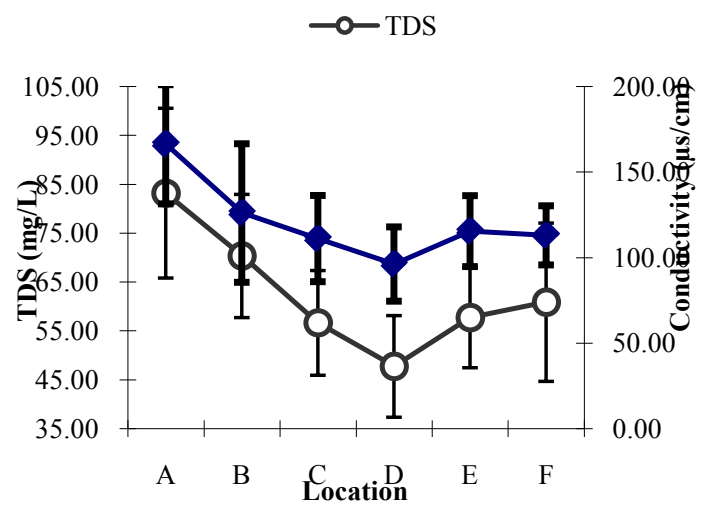

Figure 4. Annual Estimated Mean Variations of TDS (mg/L)and Conductivity $(\mu \mathrm{s} / \mathrm{cm})$ at different Locations of the River Yobe

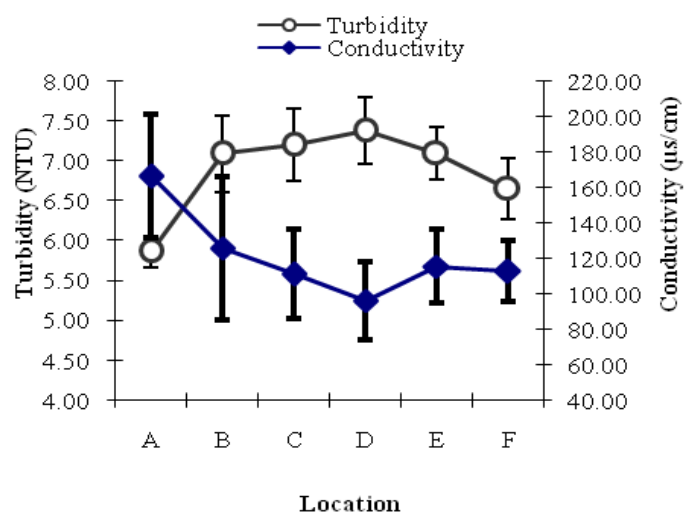

Figure 5. Annual Estimated Mean Variations of Turbidity (NTU) and Conductivity $(\mu \mathrm{s} / \mathrm{cm})$ at different Locations of River Yobe

The inter relationship between parameter is further emphasized by the plots of turbidity, TDS and conductivity (Figure 4 and Figure 5). These show the annual projected variations within the sampled areas which indicate a decrease in TDS with decrease in the conductivity, while a reserve case was observed for the turbidity and conductivity. The use of regression analysis to predict water quality indices has been reported[25].

Linearity between conductivity and TDS resulting from high salinity in lakes has also been established[26], contrary to the non linear relationships established in this work. The pattern found in this study may be due to the variable nature of the conductive mobility of the ionic species in the water. Furthermore, the presence of the non-conducting clays and sand materials in the water led to the turbidity of the water, so the higher the levels of these materials, the lower the conductivity of the water body. This inverse relationship between conductivity and turbidity was also demonstrated by Koning and Ross[27] who found that seasonal changes was responsible for the variations in the parameters.

\section{Conclusions}

Seasonal variations in conductivity, total dissolved solids and turbidity of river Yobe water samples were investigated and results showed both seasonal and location variations. Annual variations in the parameters were computed and relationships were established which can provide an instant highlight or a guide on which parameter to focus on. This suggests that the established relationships can provide a guide for prediction or forecasting in order to maintain quality of the water.

\section{REFERENCES}

[1] Waziri, M. and Ogugbuaja, V.O., Inter relationships between physico chemical water pollution indicators: A case study of River Yobe-Nigeria AJSIR 1(1): 76-80, 2010.

[2] Mulla, J.G., Farooqui, M. and Zaheer, A., A correlation and regression equations among water quality parameters. Int. J. Chem. Sci., 5(2): 943 -952, 2007.

[3] Kumar, J., Jana, A.K., Bansal, A. and Garg, R., Development of correlation between BOD and COD for refinery waste. Indian J. Env. Prot., 25(5): 405-409, 2005.

[4] Liao, H.H. and Tim, U.S., Interactive water quality modelling within GIS environment. 18: 343-363, 1994.

[5] APHA (American Public Health Association)., Standard methods for the examination of water and wastewater. 18th ed. American Public Health Association, Washington, DC, 1992.

[6] Massdam, R. and Smith, D.G., New Zealand's national river water quality network. 2. Relationships between physico -chemical data and environmental factors. New zealand Jour. Mar. FreshW. Res. 28: 37-54, 1994.

[7] Kumar, N. and Sinha, D.K., Drinking water quality management through correlation studies among variousphysi cochemical parameters: A case study. Int. Jour. Env.Sci. 1(2): 253-259, 2010 .

[8] Hayashi, M., Temperature-electrical conductivity relation of water for environmental monitoring and geophysical data nversion. Environmental Monitoring and Assessment 96: 19-128, 2004.

[9] Meshal, A.H. and Morcos, S.A., The relations between chlorinity, conductivity ratio and salinity in the water of Lake Qarun, Egypt. ICES Jour. Mar. Sci. 39(1): 20-25, 1980.

[10] Wang, X., and Yin, Z.Y., Using GIS to assess the relationship between land use and water quality at a watershed level. Environmental International 23(1): 103-114, 1997.

[11] Vieux, B.E., Geographic Information Systems and nonpoint source water quality and quantity modelling. Hydrol. Processes 5: 101-113,1991.

[12] Kaye, N. and Laslo, A.N., Relationship between bacterial growth and some physical and chemical parameters within Sydney's drinking water distribution system. Water Research. 33(3): 751- 759, 1999. 
[13] Michaud, J.P., A citizen's guide to understanding and monitoring lakes and streams. Publ. 94-149. Washington State Department of Ecology, Publications Office, Olympia, WA, USA 360: 407-7472, 1991.

[14] Moore, M.L., NALMS management guide for lakes and reservoirs. North American Lake Management Soceity, Madison, WI, 53705-5443, USA (http:/www.nalms.org), 1989.

[15] Dimari, G.A., Hati, S.S., Waziri, M. and Maitera, O.N.,Pollution Synergy from Particulate Matter Sources: The Harmattan, Fugitive Dust and Combustion Emisssions in Maiduguri Metropolis, Nigeria. Eur. Jour. Sci. Res. 23(3): 465-473, 2008.

[16] Kaufman, Y.J., Koren, I., Remer, L.A., Tanre, D., Ginoux, P.and Fan, S., Dust transport and deposition observed from theTerra- Modis spacecraft over the Atlantic Ocean. Jour.Geographical Research. 110(D10S12), 1-16, 2005.

[17] Centeno, J.A., Cook, A. and Weinstein, P., Environmental Toxicology and exposure to natural dust. The role of trace elements. Chinese Journal of Geochemistry 25(1): 222-223, 2006.

[18] Juranek, D.D. and Mackenzie, W.R., Drinking Water Turbidi-ty and Gastrointestinal Illness. Epidemiology 9(3): 228-231, 1998.

[19] Burton, A.C. and Cornhill, J.F., Correlation of cancer deathrates with altitude and with the quality of water supply of the 100 largest cities in the United States. Journal of toxicology and environmental health. 3(3): 465-473, 1977.

[20] Craun, G.F. and McGabe, L.J., Problems associated with metals in drinking water. Journal of the American water works Association. 67: 593-595, 1975.

[21] WHO (World Health Organization)., WHO Guidelines for Drinking Water Quality. First addendum to 3rd Edition Volume 1., 2006.

[22] NIS (Nigerian Industrial Standard )., Nigerian Standard for Drinking Water Quality. NIS 554 pp. 7-11, 2007.

[23] Keulder, P.C., Hydrochemistry of the upper Orange River catchment. J. Limnol. Soc. South. Afr. 5 (1): 36-46, 1979.

[24] Ferrar, A.A., Ecological Flow Requirements for South African Rivers. South African National Scientific Programmes, Report no.162, 1989.

[25] Rene, E.R. and Saidutta, M.B., Prediction of Water Quality Indices by Regression Analysis and Artificial Neural Networks. Int. Journ. Environ. Res. 2(2): 183-188, 2008.

[26] Williams, WD., Conductivity and the concentration of total dissolved soilds in Australian lakes. Australian Journal of Marine and Freshwater Research 17(2): 169-176, 1966.

[27] Koning, N. and Ross, J.C., 1The continued influence of organic pollution on the water quality of the turbid Modder River. Water S.A. 25(3): 285-292, 1999. 